\title{
The air panic of 1935: British press opinion between disarmament and rearmament
}

\author{
Brett Holman
}

[This version of the paper was accepted in February 2010. It has undergone peer review. The final, definitive version of this paper has been published in Journal of Contemporary History, volume 46, issue 2, April 2011 by SAGE Publications Ltd, All rights reserved.

(C) Brett Holman]

\begin{abstract}
The British fear of bombing in the early 20 th century has aptly been termed 'the shadow of the bomber'. But the processes by which the public learned about the danger of bombing are poorly understood. This paper proposes that the press was the primary source of information about the threat, and examines a formative period in the evolution of public concern about airpower, the so-called air panic of 1935, during which German rearmament was revealed and large-scale RAF expansion undertaken in response. A proposed air pact between the Locarno powers enabled a shift from support of disarmament to rearmament by newspapers on the right, while simultaneously supporting collective security. Paradoxically, after initially supporting the air pact, the left-wing press and its readers began to have doubts, for the same reason: the need to support collective security. This episode sheds new light on early rearmament, and how the government was able to undertake it, despite the widespread feelings in the electorate in favour of disarmament.
\end{abstract}

Britain's fear of the bomber in the 1930s is well known, but surprisingly little studied. Most historians have concentrated on the view from above, exploring how (or indeed, whether) the Royal Air Force (RAF) became wedded to an offensive doctrine based on strategic bombing. Much work has also been done on the influence on airpower policy of politicians, both in Cabinet and in Parliament, and on the internecine battles over funding between the armed forces. ${ }^{1}$ But how did the British public understand and respond to the

\footnotetext{
${ }^{1}$ The most important histories of British airpower include Barry D. Powers, Strategy Without Slide-Rule: British Air Strategy 1914-1939 (London 1976); Uri Bialer, The Shadow of the Bomber: The Fear of Air Attack and British Politics, 1932-1939 (London 1980); Malcolm Smith, British Air Strategy between the Wars (Oxford 1984); David Edgerton, England and the Aeroplane: An Essay on a Militant and Technological Nation (Basingstoke and London 1991); Michael Paris, Winged Warfare: The Literature and Theory of Aerial Warfare in Britain, $1859-1917$ (Manchester and New York 1992); Tami Davis Biddle, Rhetoric and Reality in Strategic Air Warfare: The Evolution and Reality of British and American Ideas about Strategic Bombing, 1914-1945 (Princeton 2002). For the international context, see George H. Quester, Deterrence before Hiroshima: The Airpower Background of Modern Strategy (New Brunswick and Oxford 1986 [1966]).
} 
threat of aerial bombardment? This question has suffered a relative neglect, despite its obvious significance for our understanding of the great issues of the 1930s: collective security, disarmament, rearmament, and above all, appeasement. ${ }^{2}$ Ordinary people figure in the air force view of history largely as passive victims, potential or actual. It is implicitly assumed that their understanding of airpower was a simple reflection of more sophisticated ideas held by the RAF or the government, or worse, of being of no consequence. But as Catherine Krull and B.J.C. McKercher note in relation to disarmament policy, "politicians of every stripe were cognizant of the power of "public opinion" that, exercised through the ballot box, could make or break governments in elections'. ${ }^{3}$ For Uri Bialer, public opinion was 'a catalyst, affecting official views on defence policy and - in general terms - influencing the choice of the form which rearmament was to take'. A study of the popular fear of air attack would therefore complement our understanding of British decision-making in relation to defence and foreign policy. What did ideas did British civilians hold about the dangers of bombing, and why did they hold them?

But assessing public opinion in Britain before the introduction of systematic opinion polling and Mass Observation in the late 1930s is a perennial problem, to which no better solution has yet been found than the press. There are three major reasons for this. The first is influence. In 1935, the press was for most people still the most important source of information about the wider world. Newsreels could not go into issues in any great depth, and radio did not come into its own until the Sudeten crisis in $1938 .{ }^{5}$ On the other hand, books were read by relatively small numbers of people. Only newspapers both reached a

${ }^{2}$ A rare exception is Uri Bialer, 'Elite opinion and defence policy: air power advocacy and British rearmament during the 1930s', British Journal of International Studies 6 (1980), 32-51. See also Robert Mackay, Half the Battle: Civilian Morale in Britain during the Second World War (Manchester and New York 2002), chapter 1; Malcolm Smith, Britain and 1940: History, Myth and Popular Memory (London and New York 2000), chapter 2. On public opinion and defence issues in the 1930s more generally, see Patrick Kyba, Covenants Without the Sword: Public Opinion and British Defence Policy, 1931-1935 (Waterloo 1983); Daniel Waley, British Public Opinion and the Abyssinian War, 1935-6 (London 1975).

${ }^{3}$ Catherine Krull and B.J.C. McKercher, 'The press, public opinion, arms limitation, and government policy in Britain, 1932-34: some preliminary observations', Diplomacy and Statecraft 13 (2002), 105. This does not mean that the government was a slave to public opinion, of course: as Patrick Kyba points out, in 1934 it took the decision to begin rearmament despite the pacifist temper of most of the electorate. Kyba, op. cit., 200. ${ }^{4}$ Bialer, 'Elite opinion and defence policy', 32.

${ }^{5}$ Aside from Sir John Simon's broadcast on 3 February 1935 announcing the AngloFrench air pact proposal, the BBC did not play a significant role during the air panic. Although 98 per cent of the population could tune in to at least one BBC programme in 1935, its news services were still rudimentary compared with their state by 1939 . Asa Briggs, The History of Broadcasting in the United Kingdom, volume 2 (London 1965), $152,253$. 
truly mass audience and provided both information and analysis. ${ }^{6}$ The second reason is expression. Unlike radio and newsreels, newspapers allowed for a form of interactive feedback from their audience, in the form of letters to the editor. This provides some insight into the reaction of readers to what they were reading. ${ }^{7}$ The final reason for concentrating on newspapers, and the most important, is that the political and administrative classes in the interwar period generally assumed that the press did have the pulse of the nation. To a large extent, Britain's leaders relied on newspapers to tell them what the public was thinking on any given topic. ${ }^{8}$ The alarm caused in 1935 by the imminent prospect of German aerial rearmament provides an ideal opportunity to study press opinion on airpower.

One important property of newspapers as sources is the political and economic segmentation of their readership. ${ }^{9}$ Most newspapers had a definite political stance, whether explicit or otherwise. Of the national dailies with a circulation of a million or more, the Daily Express and Daily Mail were Conservative, albeit often strongly critical of the party's leadership and policies; the Daily Herald was Labour, indeed part-owned by the Trades Union Congress; and the News Chronicle was Liberal. The Daily Mirror was a special case: previously Conservative, in 1935 it was in the middle of a transition to a much more left-wing position. ${ }^{10}$ Also influential, despite having relatively small readerships, were the Daily Telegraph and The Times, both Conservative; the Manchester Guardian, Liberal. Important weekly publications include the left-wing New Statesman, and the right-wing Observer (under the veteran editor J.L. Garvin), Spectator and Saturday Review. Of course, such broad categories do not tell the whole story. A centreright weekly like the Spectator was a long way from the isolationist Daily Express, which itself was not as extreme in its xenophobia as Lady Houston's Saturday Review. Similarly, The Times catered for an upper-class audience, whereas the Daily Mail aimed much more squarely at the middle classes; and the Fabianism of the New Spectator often

\footnotetext{
${ }^{6}$ In a survey carried out by Mass-Observation at the end of August 1938, 1100 people were asked 'On what do you base your opinion?' The most common answer was newspapers at $35 \%$, followed by friends at $17 \%$ and radio at $13 \%$. Charles Madge and Tom Harrisson, Britain by Mass-Observation (Harmondsworth 1939), 50.

${ }^{7}$ We cannot assume that such letters are representative of the opinions of a newspaper's readership, since by definition they were written by unusually engaged readers, and then were selected and perhaps rewritten for publication by an editor. But some newspapers, such as The Times, tried to print a representative sample of letters in their pages, even where this contradicted their own editorial position. Kyba, op. cit., 5.

${ }^{8}$ Krull and McKercher, op. cit., 107-8, 127.

${ }^{9}$ See the discussion in Ross McKibbin, Classes and Cultures: England 1918-1951 (Oxford 1998), 503-8.

${ }^{10}$ Martin Pugh, 'The Daily Mirror and the revival of Labour 1935-1945', Twentieth Century British History 9 (1998), 420-38.
} 
had little in common with the working-class politics of the Daily Herald. Such nuances affected both the style and the content and need to be borne in mind. ${ }^{11}$

We cannot assume that readers simply believed what newspapers told them to believe, however. Indeed, the existence - in at least some newspapers - of vigorous debate in the letter columns shows this. But imperfect a gauge of public opinion as newspapers are, it is the best we have.

The press did not invent the idea of the knock-out blow. It drew on a discourse about the threat of aerial bombardment which had been developed by a number British aviation writers over the previous quarter of a century. ${ }^{12}$ Collectively, they argued that the coming of aviation had fundamentally changed war, making it faster and more destructive and crucially - aimed principally at civilians rather than soldiers and sailors. The First World War itself was crucial to the genesis of the knock-out blow theory: it demonstrated the importance of the consent of the civilian populace in sustaining a modern war effort, it showed that aircraft were now practical weapons, and it brutalised the imagination of those who lived through it. ${ }^{13}$ The Zeppelin raids on Britain from 1915 proved that the bombing of cities was not merely a theoretical possibility, and the heavy Gotha raids of 1917 and 1918 seemed to show that bombers could always get through any air defence. As aviation technology continued to develop in leaps and bounds throughout the 1920s and early 1930s, the power of the bomber to devastate cities only increased. Finally, the

${ }^{11}$ See Stephen Koss, The Rise and Fall of the Political Press in Britain (London 1984), volume 2, chapter 14; Benny Morris, The Roots of Appeasement: The British Weekly Press and Nazi Germany during the 1930s (London and Portland 1991).

${ }^{12}$ Important writers in this literature include Lord Montagu of Beaulieau, F.W. Lanchester, Claude Grahame-White and Harry Harper before and during the First World War, and P.R.C. Groves, J.F.C. Fuller, Basil Liddell Hart and J.M. Spaight during the 1920s and early 1930s. See Michael Paris, Winged Warfare: The Literature and Theory of Aerial Warfare in Britain, 1859-1917 (Manchester and New York 1992), 80-3; Powers, op. cit.; Robin Higham, The Military Intellectuals in Britain: 1918-1939 (Westport 1966), 126-32, 170-5, 230-3; Azar Gat, Fascist and Liberal Visions of War: Fuller, Liddell Hart, Douhet and Other Modernists (Oxford and New York 1998). Giulio Douhet is widely cited as one of the most influential airpower theorists, but his writings were only just becoming known in Britain by 1935 and so played little direct role. See ibid., 54-5.

${ }^{13}$ Jon Lawrence, 'Forging a peaceable kingdom: war, violence and fear of brutalization in post-First World War Britain', Journal of Modern History 75 (2003), 557-89; John H. Morrow, The Great War in the Air: Military Aviation from 1909 to 1921 (Washington DC and London 1993); Alan Kramer, Dynamic of Destruction: Culture and Mass Killing in the First World War (Oxford 2007). 
possibility of poison gas being delivered by aircraft against civilians added a terrifying new dimension to the discourse of aerial warfare. ${ }^{14}$

The idea of a knock-out blow from the air was first given wide publicity in a series of articles written in 1922 for The Times by Brigadier-General P.R.C. Groves, former British representative on military aviation to the League of Nations. Although it was never formally described in this way, by the early 1930s the theory of the knock-out blow consisted of most or all of a small number of stereotypical elements. First, that the next war would begin in the air, with a sudden attack by enemy bombers on civilian targets. Second, that the attack would be unprecedented in scale. Third, that the complex, interdependent nature of modern civilisation would make it vulnerable to attack. Fourth, that civilian morale would be easily and fatally weakened by such attacks. Fifth, that defeat would come extremely rapidly, in a matter of weeks rather than years. Sixth, that destruction would be horrific. A successful knock-out blow would avoid repeating the bloody stalemate of the Western Front, but at the cost of the lives of tens or hundreds of thousands of civilians. Britain was widely assumed to be especially vulnerable to a knock-out blow, since London, its densely-populated political, cultural and commercial capital, was situated close to the coast and close to any likely European attacker. There was no anticipation of the 'Blitz spirit': a British collapse might come mere days after the start of war. ${ }^{15}$

While the scenarios sketched out by airpower writers of the destruction of British society were uniformly pessimistic, they were usually followed by suggestions for preventing such a disaster. There were three main types of response to the threat of a knock-out blow. The first category was resistance, through air defence or by counter-bombing. The second was adaptation, by instilling discipline in the civilian population, evacuating it, or building shelters to protect it. The third was negotiation, by reaching agreements with other nations on disarmament or by forming an international air force to punish any country which started a war. Of these, counter-bombing was overwhelmingly the response favoured by military experts, and it was the declared policy of the RAF itself. ${ }^{16}$ If, as Stanley Baldwin told the House of Commons in 1932, it was true that 'the bomber will always get through' any air defences, then his conclusion was also sound: 'The only

\footnotetext{
${ }^{14}$ Powers, op. cit.; Raymond H. Fredette, The Sky on Fire: The First Battle of Britain 1917-1918 and the Birth of the Royal Air Force (Washington, D.C. 1991); Marion Girard, A Strange and Formidable Weapon: British Responses to World War I Poison Gas (Lincoln and London 2008), chapter 6.

${ }^{15}$ Brett Holman, 'The Next War in the Air: Civilian Fears of Aerial Bombardment in Britain, 1908-1941', Ph.D. thesis (University of Melbourne 2009). Of course, notwithstanding the terrible damage inflicted by bombers during the Second World War, a knock-out blow in this sense never took place.

${ }^{16}$ Jones, op. cit., 32-46. In theory, a RAF bomber force could be used to initiate a knockout blow against an enemy nation, but despite the legacy of Copenhagen in 1801 and 1807, in the era of Versailles and Locarno it was almost impossible for contemporaries to imagine Britain carrying out such a pre-emptive attack. See, e.g., E.B. Ashmore, Air Defence (London 1929), 149.
} 
defence is in offence, which means that you have got to kill more women and children more quickly than the enemy if you want to save yourselves'. ${ }^{17}$ This meant that Britain needed a bomber force capable of inflicting enough damage on an enemy to deter an attack or at least halt one in progress. If the knock-out blow was the default airpower theory held in Britain, then counter-bombing was the default response.

There was little dissent from the theory of the knock-out blow, even from peace advocates. Indeed, the widespread fear of bombing partly explains why previously minority viewpoints such as pacifism and collective security were so strongly supported in interwar Britain. The Reverend Dick Sheppard's Peace Pledge Union was formed in October 1934, quickly reaching 135,000 members, and older groups such as the Women's International League for Peace and Freedom were still active. ${ }^{18}$ The hope vested in collective security is even more striking: the League of Nations Union (LNU) had a little over 400,000 members in 1931 (though recruitment declined thereafter due to the Slump). Some 11 million men and women across the nation cast their votes in the Peace Ballot during 1934 and 1935, favouring collective security and disarmament by large margins. ${ }^{19}$ Pacifists eagerly accepted the contention of the airpower theorists that aerial warfare would be enormously destructive of life and property, as it meshed perfectly with their beliefs. In contrast to more militarist opinion, however, pacifists argued its very destructiveness meant that it was better to prevent war from starting at all, by removing the root causes of war. In other words, they would prefer to rely upon negotiation with a potential enemy, rather than resistance. ${ }^{20}$ Only a small number of writers rejected the premises of the knock-out blow theory outright, mainly those writing from a naval or military viewpoint. ${ }^{21}$ These generally did not dispute that the coming of flight had changed warfare to a large degree, but denied the claims of the most radical airpower theorists that it overturned accepted principles of strategy and the lessons of history.

The understanding of airpower inside the Air Ministry and the RAF was more nuanced and less extreme, but - despite the existence of a strong lobby for the value of air defence - was nonetheless dominated by an emphasis on the near-absolute power of the strategic

${ }^{17}$ HC Deb, 10 November 1932, vol. 270, col. 632.

${ }^{18}$ David C. Lukowitz, 'British pacifists and appeasement: the Peace Pledge Union', Journal of Contemporary History 9 (1974), 115-27; Jill Liddington, The Long Road to Greenham: Feminism and Anti-Militarism in Britain since 1820 (London 1989), 146-51, 154-8. On pacifism in interwar Britain generally, see Martin Ceadel, Pacifism in Britain 1914-1945: The Defining of a Faith (Oxford 1980).

${ }^{19}$ Though this leaves open the question of what voters understood 'collective security' to mean. Donald S. Birn, The League of Nations Union 1918-1945 (Oxford 1981), 129-30; J.A. Thompson, 'The Peace Ballot and the public', Albion 13 (1981), 381-92.

${ }^{20}$ E.g., H.M. Swanwick, New Wars for Old (London 1934).

${ }^{21}$ E.g., Neon, The Great Delusion: A Study of Aircraft in Peace and War (London 1927). 
offensive. ${ }^{22}$ This official attitude was conveyed to the public by a number of methods, some quite novel. The Hendon Air Pageant, held annually since 1920, climaxed with a spectacular set piece where RAF bombers destroyed an Asian village or desert stronghold. ${ }^{23}$ Every summer between 1927 and 1934, the RAF held well-publicised exercises designed to test the ability of bombers to penetrate London's air defences, which almost uniformly resulted in a victory for the 'attacking' side. ${ }^{24}$ And when even the commander of Britain's fighter defences could tell Londoners in a 1926 lecture that 'Fighting in the air on a large scale only takes place by accident or by mutual consent', it is clear that the phrase 'the bomber will always get through' was practically an orthodoxy by the time Baldwin uttered it. ${ }^{25}$

Despite all the rhetoric, during the 1920s and early 1930s the danger of bombing was merely theoretical. ${ }^{26}$ Another great war seemed a distant prospect, and aside from a brief burst of concern in 1922 about the growth of airpower on the Continent, public interest in the possibility of an attack from the air was only sporadic. ${ }^{27}$ This began to change in 1934 , indirectly due to the rise to power in Germany of Adolf Hitler, but more directly because of the lack of progress at the World Disarmament Conference which had been in session at Geneva since 1932. As time passed it became clear that the Conference was unlikely to reach any agreement, let alone a universal one: Germany's withdrawal in

22 John Ferris, 'Fighter defence before Fighter Command: the rise of strategic air defence in Great Britain, 1917-1934', Journal of Military History 63 (1999), 845-84; Biddle, op. cit., chapter 2.

${ }^{23}$ David E. Omissi, 'The Hendon Air Pageant, 1920-1937', in John M. MacKenzie, ed., Popular Imperialism and the Military: 1850-1950 (Manchester 1992), 198-220; Jack Williams, 'The upper class and aeroplane sport between the wars', Sport in History 28 (2008), 457-8.

${ }^{24}$ Powers, op. cit., 196-9. But see Ferris, 'Fighter defence before Fighter Command', 863-4.

${ }^{25}$ H.R.M. Brooke-Popham, 'Air warfare' in George Aston, ed., The Study of War for Statesmen and Citizens: Lectures Delivered in the University of London during the Years 1925-6 (London 1927), 159.

${ }^{26}$ The danger was merely theoretical for the inhabitants of Britain, but quite real for those of its own colonies and mandated territories: Priya Satia, 'The defense of inhumanity: air control and the British idea of Arabia', American Historical Review 111 (2006), 16-51; Yuki Tanaka, 'British "humane bombing" in Iraq in the interwar era', in Yuki Tanaka and Marilyn B. Young, eds., Bombing Civilians: A Twentieth-Century History (New York and London 2009), 8-29; David E. Omissi, Air Power and Colonial Control: The Royal Air Force 1919-1939 (Manchester and New York 1990).

27 John Ferris, "The theory of a "French air menace": Anglo-French relations and the British Home Air Defence programmes of 1921-25', Journal of Strategic Studies 10 (1987), 62-83. 
October made this a certainty. ${ }^{28}$ As Hitler was a vocal critic of the Versailles restrictions on German rearmament, which included a complete ban on military aviation, the creation of an illegal German air force was just a matter of time. In Britain, pacifists and militarists alike now began to warn of the increasing danger of war. Beverly Nichols' investigation of whether pacifism in the face of fascism was even possible became a runaway bestseller, and a group of peace-minded intellectuals collaborated to produce a volume entitled Challenge to Death. In 1933, H.G. Wells published The Shape of Things to Come, another of his apocalyptic visions of the next war, in which aircraft and poison gas played an important part. ${ }^{29}$ Groves warned of Britain's aerial weakness in Behind the Smoke Screen, and veteran journalist Wickham Steed stunned the nation with his revelations about secret German experiments on the vulnerability of the London Underground to bacteriological weapons. ${ }^{30}$ Ramsay MacDonald's National government began to plan rearmament, a process for which Baldwin, as the leader of the dominant Conservatives and Lord President of the Council, acted as public spokesman.

Despite the plans for a 52-squadron metropolitan air force which had been put in place as long ago as 1923, financial stringency and gestures towards disarmament meant that by 1933 the RAF's air strength at home stood at just 13 squadrons of fighters and 12 of bombers. ${ }^{31}$ The largest air force in the world in 1918, it now ranked only fifth. In Europe's increasingly unsettled climate, this was plainly not enough. As Baldwin said in July 1934,

since the day of the air, the old frontiers are gone. When you think of the defence of England you no longer think of the chalk cliffs of Dover: you think of the Rhine. That is where our frontier lies. ${ }^{32}$

${ }^{28}$ Bialer, Shadow of the Bomber, 46; Carolyn J. Kitching, Britain and the Problem of International Disarmament, 1919-1934 (London and New York 1999), chapter 8. Germany simultaneously announced its withdrawal from the League of Nations.

${ }^{29}$ Beverly Nichols, Cry Havoc! (London 1933); Challenge to Death (London 1934); H.G. Wells, The Shape of Things to Come: The Ultimate Revolution (London 1933). On Challenge to Death, see Richard Overy, The Morbid Age: Britain Between the Wars (London 2009), 219-24. On The Shape of Things to Come and other predictive literature on the next war, see Martin Ceadel, 'Popular fiction and the next war, 1918-1939', in Frank Gloversmith, ed., Class, Culture and Social Change: A New View of the 1930s (Brighton 1980), 161-84. Wells' influence can be seen in the common descriptions of the Blitz as 'Wellsonian' or similar: e.g. Angus Calder, The People's War: Britain 1939-1945 (London 1969), 206.

${ }^{30}$ P.R.C. Groves, Behind the Smoke Screen (London 1934); H. Wickham Steed, 'Aerial warfare: secret German plans', Nineteenth Century and After 116 (July 1934), 1-15. On Steed, see Martin Hugh-Jones, 'Wickham Steed and German biological warfare research', Intelligence and National Security 7 (1992), 379-402.

${ }^{31}$ John James, The Paladins: A Social History of the RAF up to the Outbreak of World War II (London and Sydney 1990), 249.

${ }^{32}$ HC Deb, 30 July 1934, vol. 292, col. 2339. 
Baldwin spoke these words in the House of Commons while introducing a five-year plan for the expansion of the RAF, partly at the expense of an increase in military and naval expenditure. This took the form of a gradual rise in first-line aircraft numbers to keep parity with Germany's predicted air strength over the next five years. But it soon became clear to the government that Germany was rearming at a faster rate than was thought, prompting an acceleration of the RAF's own schedule in November $1934 .{ }^{33}$ However, Winston Churchill pre-empted an orderly release of this news by initiating a Commons debate on the neglect of Britain's air defences, making his first major speech on the subject. Although Churchill was still on the backbenches, he had access to confidential official estimates of German aircraft production, and used them to attack the government for its complacent approach to national security. Baldwin was able to salvage the situation by revealing the new plan, which Cabinet had approved only days before. But Churchill's criticism forced him to promise that the RAF's home forces would still be nearly 50 per cent stronger than the nascent German air force in two years' time. ${ }^{34}$ In March 1935, however, Hitler claimed to the Foreign Secretary, Sir John Simon, that Germany already had air parity with Britain, and was aiming for parity with France, at around 1500 first-line aircraft. Although his claim greatly exaggerated the Luftwaffe's real strength, it sowed confusion in Whitehall. ${ }^{35}$ As a consequence, in May Baldwin announced a further acceleration of the RAF's expansion programme which would triple its home forces within two years. This was the Air Ministry's Scheme C, which included 25 squadrons of fighters for home defence, 20 of heavy bombers and 18 of medium bombers. ${ }^{36}$

The main purpose of RAF expansion was not to start an arms race, but to prevent one, by demonstrating that Britain would maintain parity in the air, whatever actions Germany took. ${ }^{37}$ It was also intended to deter a knock-out blow through the threat of counterbombing. But Cabinet also considered it necessary to find a way to legitimise Germany's illegal rearmament, so that it could be managed through diplomatic means. To this end, the French premier, Daladier, was invited to Downing Street for talks at the end of

${ }^{33}$ Smith, op. cit., 143-5; Bialer, Shadow of the Bomber, 69-70. Quantifying the strength of an air force was not easy, even setting aside the difficulty of getting reliable intelligence. The usual standard adopted in discussions of air parity, that of first-line strength, was deemed appropriately simple for the public to understand. But this neglected the need for reserves, flattering the rapidly growing Luftwaffe at the expense of the relatively long-established RAF. Similarly, the focus on parity ignored wide variations in the type and quality of the aircraft on both sides. A large share of German aircraft production in 1934-5 was necessarily devoted to trainers. See Wesley K. Wark, The Ultimate Enemy: British Intelligence and Nazi Germany, 1933-1939 (Oxford 1986), 47-8; Corum, The Luftwaffe, 163-4.

${ }^{34}$ Wark, op. cit., 42; R.A.C. Parker, Churchill and Appeasement (London 2000), 45-8.

${ }^{35}$ Bialer, Shadow of the Bomber, 70; Ian Kershaw, Making Friends With Hitler: Lord Londonderry and Britain's Road to War (London 2004), 100-4. The Foreign Office was considerably more rattled than the Air Staff: Wark, op. cit., 43-7; Smith, op. cit., 150.

${ }^{36}$ Ibid., 155-8, 329.

${ }^{37}$ Ibid., 144. 
January 1935. The most notable result of this meeting was a French idea, the proposal for an air pact. Britain and France invited the other signatories to the Locarno Pact Germany, Italy and Belgium - to agree to use their air forces to assist any of them in the event that they were bombed by one of the other signatories. Unusually, Simon went on the BBC to explain the proposal to the nation, even before informing Parliament. According to Simon, an air pact 'would go far to ensure immunity from sudden attacks from the air ${ }^{38}$ Reactions from Belgium and Italy were largely positive; Germany was less forthcoming but eventually - and surprisingly - accepted the 'air Locarno' as a basis for discussion. ${ }^{39}$

Finally, in July 1935, the Home Office distributed a circular on ARP to local authorities. While this was done in a relatively low-key fashion - there was no announcement in Parliament, let alone a BBC broadcast - it did mark the start of the official ARP public education campaign. The government promised to provide advice on the design of airraid shelters, but no money to help with their construction. It was left up to local authorities to provide protection for their own residents largely out of their own financial resources. ${ }^{40}$

In the meantime, however, events on the Continent were moving fast. Germany announced the existence of the Luftwaffe on 9 March, and resumed conscription a week later. France extended its conscription period to two years in response; the Stresa Front and the Franco-Soviet Pact soon followed. War was by no means imminent, but it was also no longer unthinkable. With the air Locarno proposal, RAF expansion, and the ARP programme, Britain's public response to the problem of the bomber had begun in earnest. But how did the press respond?

In the light of what we know happened later in the Battle of Britain, the obvious response to the German air menace might have been to call for an increase the number of defensive fighter aircraft and, perhaps, anti-aircraft guns. But as has already been shown, Baldwin's dictum that 'the bomber will always get through' had been taken very much to heart, and it was almost universally assumed in the public sphere that 'air defence', and hence the quest for parity, actually meant the acquisition of bombers and not fighters. For example, C.C. Turner, the air correspondent for the Daily Telegraph, analysed the RAF expansion

\footnotetext{
${ }^{38}$ Sir John Simon, BBC broadcast, 3 February 1935; reprinted in The Listener, 6 February 1935, 239.

${ }^{39}$ On the air pact - sometimes known as the Western air pact or the air Locarno - see Bialer, Shadow of the Bomber, chapter 3; Smith, op. cit., 148-51; Keith Middlemas and John Barnes, Baldwin: A Biography (London 1969), 790-5. The Foreign Office was in favour of the air pact; the Chiefs of Staff were far less sure. For a sceptical insider view, see Stephen Roskill, Hankey: Man of Secrets (London 1974), vol. 3., 155-64. On the Locarno Pact proper, see Zara Steiner, The Lights that Failed: European International History 1919-1933 (Oxford 2005), 396-7.

${ }^{40}$ Terence H. O’Brien, Civil Defence (London 1955), 56-60.
} 
announced in May, and in the context of home defence concentrated on the problems being encountered in developing a new type of heavy bomber, mentioning fighters only in passing. ${ }^{41}$ As another example, in June 1934 the inaugural meeting of the 'Hands Off Britain' Air Defence League, a pressure group formed by Oliver Locker Lampson MP and fellow Conservatives Murray Sueter and the Duchess of Atholl, did not call for more fighters, as its name might suggest. Instead it demanded the creation of 'a new winged arm of long-range bombers, which would make the voice of England paramount again'. ${ }^{42}$ There was even less interest in anti-aircraft weapons, and other 'scientific' aids to defence. One important exception, however, is the debate initiated by the physicist F.A. Lindemann in The Times in August 1934. Lindemann protested that all sides in the recent Commons debate had assumed that 'there is and can be no defence against bombing aeroplanes and that we must rely entirely upon counter-attack and reprisals'. He accepted that this was presently true, but argued that the government should throw its weight behind the search for a scientific solution to the problem. ${ }^{43} \mathrm{He}$ was challenged by Geoffrey Mander, a Liberal MP and a well-known supporter of collective security and an international air force. ${ }^{44}$ A number of other writers weighed in, including another MP and a fellow physicist, but few of them seemed to understand what Lindemann was talking about, such was the lack of faith in anti-aircraft weapons. ${ }^{45}$ Finally, ARP was given very little credence. The press did run articles on the occasional ARP exercise in early 1935. For example, a mock gas attack near Winchester for the training of Red Cross nurses led to articles in a number of newspapers. But the accompanying photographs of young women in gas masks performing first-aid in simulated smoke, along with captions such as 'FASHIONS - OF WAR!' suggest that these cannot be read as a commentary on the need for more ARP. ${ }^{46}$ Several newspapers commented on the publication of the ARP circular in July, but with little enthusiasm. The Daily Express at that time thought it "wise to do what is possible to mitigate the terrors of air invasion'. But even so, it argued that the only sure way of saving Britain from the bomber was to avoid foreign entanglements altogether. Failing that,

${ }^{41}$ C.C. Turner, 'Nearly 2,000 first-line aircraft by 1937', Daily Telegraph, 23 May 1935, 15.

${ }^{42}$ Advertisement, The Times, 29 June 1934, 12. Little is known about the Air Defence League, but see Nowell Smith, letter, Spectator, 20 July 1934, 88.

${ }^{43}$ F.A. Lindemann, letter, The Times, 8 August 1934, 11.

${ }^{44}$ Geoffrey Le M. Mander, letter, ibid., 10 August 1934, 11.

${ }^{45}$ Lindemann had in mind such ideas as an aerial minefield to stop night bombers: Zimmerman, Britain's Shield: Radar and the Defeat of the Luftwaffe (Stroud 2001), 85. His letters were intended to place pressure on Baldwin to allow him and Churchill access to government committees on air defence, which ultimately bore fruit in March 1935. See R.A.C. Parker, Churchill and Appeasement (London 2000), 65-7.

${ }^{46}$ News Chronicle, 22 May 1935, 20. The same images could, of course, be used for more pointed purposes, as in the Union of Democratic Control pamphlet Poison Gas (London 1935). 
neither pacifism, Quakerism, Communism, nor the League of Nations will save you. Only your own strength will avail you to hit back in what will be the most frightful of all wars. ${ }^{47}$

On this view, the best - indeed, only - defence was a good offence.

Churchill's speech to the House of Commons on 28 November 1934 encapsulates both the prevailing theory of the knock-out blow and the equation of parity with the ability to counter-bomb an aggressor. He claimed to reject the most extreme claims made by the airpower advocates, but nonetheless projected a very similar vision of London under bombardment to writers such as Groves:

no one can doubt that a week or 10 days' intensive bombing attack upon London would be a very serious matter indeed. One could hardly expect that less than 30,000 or 40,000 people would be killed or maimed.

Similarly, he predicted that at least three or four million people would flee the capital for the countryside in order to escape the bombing, and that their care and supervision would add greatly to the nation's misery:

This vast mass of human beings, numerically far larger than any armies which have been fed and moved in war, without shelter and without food, without sanitation and without special provision for the maintenance of order, would confront the Government of the day with an administrative problem of the first magnitude, and would certainly absorb the energies of our small Army and of our Territorial Force.

This too conformed to the predictions of the knock-out blow theory. While Churchill followed his friend Lindemann by urging that the possibility of "purely defensive action against aircraft attack' be studied, in the end the 'only direct measure of defence upon a great scale is the certainty of being able to inflict simultaneously upon the enemy as great damage as he can inflict upon ourselves'. ${ }^{4}$ Thus, for Churchill as for the wider public, air defence meant not interceptors and anti-aircraft guns, but bombers. Baldwin, speaking immediately after Churchill, did not disagree with Churchill's assumptions, but sought to deflect his argument by claiming that the RAF had and would maintain a sufficient safety margin over the German air force. ${ }^{49}$ Thus the terms of the air defence debate were, at the outset, framed in terms of parity.

47 'Air defence', Daily Express, 11 July 1935, 10.

${ }^{48}$ HC Deb, 28 November 1934, vol. 295 col. 859. Churchill neglected to mention in his post-war memoirs this pre-war overestimate of the chaos sustained bombing would cause in London: David Reynolds, In Command of History: Churchill Fighting and Writing the Second World War (London 2004), 99.

${ }^{49}$ HC Deb, 28 November 1934, vol. 295 cols. 872-85. 
The Conservative press was nearly unanimous in accepting the need to begin aerial rearmament. The Daily Telegraph's lobby correspondent reported that Baldwin's speech 'left no doubt of the adequacy of British preparations' for air attack, while its editor claimed there would be 'general satisfaction' in the assurance that Britain would 'end inferiority in the air'. ${ }^{50}$ For The Times, it showed that the government was 'neither panicky nor negligent about British preparations'.51 But further to the right, the new measures were attacked as insufficient. Rothermere's flagship, the Daily Mail, called Baldwin 'incorrigible' and quoted a Swedish newspaper report that Germany already had 12500 aircraft at its disposal. Set against this, an extra 300 for the RAF was a trifling amount. ${ }^{52}$ The Saturday Review went even further, accusing Baldwin of treason for his neglect of Britain's defences. Another article in the same issue claimed that even now Germany could successfully launch a knock-out blow against Britain, 'smash[ing] the resisting power of the civil will and compel[ling] surrender'. ${ }^{3}$

A few newspapers, mainly on the left, opposed the quest for parity altogether. But their criticisms focused more on form than content, as when the Daily Herald splashed its front page with headlines such as 'CABINET OPENS ARMS SCARE CAMPAIGN' and 'GERMANY AS BOGY TO ALARM M.P.s'. 54 The Daily Mirror was more contemplative, arguing that since nobody could know what the next war would be like, even 'A million aeroplanes, for example, would not make us safe' ${ }^{55}$ But the assumptions underlying the public understand of aerial warfare were rarely analysed, by either left or right, militarists or pacifists, for the simple reason that they were almost universally shared.

The difficulty in questioning the theory of the knock-out blow is made clearer by the response to a sceptical article which appeared in March in the Daily Express - itself the only newspaper to consistently question the knock-out blow paradigm up to this point. ${ }^{56}$ The author was Viscount Castlerosse, a Beaverbrook man and a popular columnist for the Sunday Express. He had endured heavy aerial bombardments while serving in the army in the last war, which 'never killed so much as a mouse'. Castlerosse argued that London could not be destroyed from the air, even if the Germans were so foolish as to expend the resources necessary to create an aerial armada of 30,000 aircraft. Any attempt at a knockout blow would fail, for 'You cannot frighten English people that way, you will only

\footnotetext{
50 'No air inferiority', Daily Telegraph, 29 November 1934, 14; "“No cause for alarm"”, ibid., 15.

51 'The curse of secrecy', The Times, 29 November 1934, 15.

52 'Incorrigible', Daily Mail, 29 November 1934, 12. Rothermere's newspapers habitually made such vastly exaggerated claims throughout the 1930s. Three months later, the Luftwaffe actually had just 800 aircraft: James S. Corum, The Luftwaffe: Creating the Operational Air War, 1918-1940 (Lawrence 1997), 164.

${ }^{53}$ Saturday Review, 1 December 1934, 450; H. Reade, 'If war broke out', ibid., 454.

54 'Cabinet opens arms scare campaign', Daily Herald, 29 November 1934, 1.

55 'Can we be safe?', Daily Mirror, 28 November 1934, 13.

${ }^{56}$ E.g., 'Don't get the air scare!', Daily Express, 8 December 1934, 10.
} 
infuriate them'. ${ }^{57}$ Castlerosse's article led to a stream of letters from readers, mostly scornful. 'Six ex-Tommies' told the Express to remind its 'pet Viscount' of the many women and children hit by German bombs in Britain during the Zeppelin and Gotha raids, while a husband and father from Wood Green asked why the paper allowed Castlerosse to 'deliberately mislead the public about the bombing of London'. According to another reader, 'The air menace is a subject for air experts - not gasbags'. ${ }^{58}$ And the air experts themselves were hardly less derisive. Sir Alan Cobham, the famous pioneer aviator, claimed that aerial navigation was now so accurate that any target in a city could be destroyed at will: 'It will be the annihilation of the population. Lord Castlerosse knows nothing about it'. Another airman was blunter: 'Lord Castlerosse was talking rot'. One expert did argue strongly in favour of Castlerosse's views - but as a senior official in the Berlin air defence organization, his views may not have carried much weight in Britain. ${ }^{59}$ That such attempts to debate the premises on which the knock-out blow rested were both so rare and so unwelcome demonstrates its power to circumvent rational thought. In any event, the Daily Express now discarded its own former scepticism, explaining that a bombing war would 'wreak such slaughter as to involve ruin for all'. Once this was understood by both sides, then mutual deterrence would result. ${ }^{60}$

The Daily Express debate may have been a response to the campaign then being waged in the Rothermere press on behalf of the National League of Airmen (NLA), which Rothermere launched at the end of January 1935 in order to 'preach the cause of aerial security throughout the land' through the press and public meetings. ${ }^{61}$ Offers of support flooded in from members of the public, as well as from famous aviators such as Amy Mollison (née Johnson) and Tom Campbell Black, one of the winners of the Mildenhall to Melbourne air race the previous October. The Daily Mail ran numerous articles throughout February on the NLA's rapid growth. It also featured a contribution from Captain Norman Macmillan, the NLA's president, on the effects of a knock-out blow by 2500 bombers on Liverpool: within two hours, it would become 'an English Ypres', and the destruction of its port would ultimately lead to starvation throughout Britain. ${ }^{62}$ Reinforcing the NLA's message was a parallel series of articles in another Rothermere paper, the Evening News, on readers' memories of the German bombing of British cities in the Great War. ${ }^{63}$ In terms of Rothermere's continuing attempts to influence Conservative policy, the NLA was a more refined, less aggressive tool than the United

${ }^{57}$ Castlerosse, 'Bombs on London will never win a war', ibid., 22 March 1935, 12.

58 'Six ex-Tommies' and C. Watson, letters, ibid., 23 March 1935, 12.

59 'Air experts for and against Lord Castlerosse', ibid., 25 March 1935, 13.

60 'To discourage war', ibid., 23 March 1935, 10.

${ }^{61}$ Rothermere, 'National League of Airmen for Britain', Daily Mail, 30 January 1935, 9. The secretary of the Air League of the British Empire, J.A. Chamier, protested that the NLA was usurping his organisation's position as the Air League: 'The two leagues', Flight, 21 February 1935, 202. But the Air League was undergoing one of its quiescent periods: the minutes of its executive council for late 1934 and early 1935 show no engagement with air policy issues such as rearmament or the air pact.

${ }^{62}$ Norman Macmillan, 'If Liverpool were bombed!', Daily Mail, 1 February 1935, 10.

${ }^{63}$ E.g. 'The air torpedo that killed my family', Evening News, 4 February 1935, 3. 
Empire Party of 1929-31. While it did demand that parliamentary candidates in the 1935 general election endorse a list of aviation-related policy positions, above all 'The creation and maintenance of an Air Force equal in size and equipment to that of any other Power', the ultimate influence of the NLA is unknown. ${ }^{64}$ But by repeating and amplifying claims of aerial peril and the consequent need for aerial parity, it reinforced the public framing of the airpower debate in simple numerical terms: the need for more bombers.

Baldwin's announcement in May of the tripling of the RAF's home forces led to a great deal of commentary in the press, most of it far more favourable than it had been the previous November. Flight welcomed the news as signifying, at long last, a final break with a discredited policy: 'To speak of unilateral disarmament is [...] like remaining a free trader in a protectionist world'. ${ }^{65}$ The Times also applauded Baldwin's speech for its measures to restore air parity as well as the positive response to Hitler's overtures regarding an air Locarno, and concluded that 'In all these matters the Government will need the support as well as the financial assistance of the nation which has approved in principle the measures contemplated for its defence'. ${ }^{66}$ The Daily Telegraph was likewise certain that the expansion 'will assuredly receive the almost universal assent of the British people'. ${ }^{67}$ Certainly, the correspondence from its own readers it chose to publish was strongly in support. Two letters published on the same day stressed the importance of getting in the first blow in aerial warfare, and the unreliability of defensive technologies. ${ }^{68}$ But the requirements of collective security were also offered as a rationale. The naval writer Archibald Hurd wrote to The Times to ask those who opposed rearmament 'what hope is there of the ideal of collective security being realized if we are not prepared to make our appropriate and proportionate contribution of armaments'? ${ }^{69}$

Pacifists were dismayed at seeing their hopes for disarmament dashed. The Society of Friends, for example, called on the nation to reject the RAF expansion programme, since 'along this path of piling up weapons of human destruction no permanent peace can ever be attained'. ${ }^{70}$ Another Quaker was blunter: 'this increase in the Air Force is the road to hell, and most of us do not want to go there'. Groups such as the Hendon Anti-Air

\footnotetext{
${ }^{64}$ Rothermere, My Fight to Rearm Britain (London 1939), 94. Little has been written about the NLA; for a brief but obviously partisan outline of its activities see Rothermere, op. cit., 89-96. Rothermere's ghostwriter, Collin Brooks, was also chairman of the NLA's advisory council; his diary provides some insight into its internal affairs. N.J. Crowson, ed., Fleet Street, Press Barons and Politics: The Journals of Collin Brooks, 1932-1940 (London 1998).

65 'Expansion', Flight, 30 May 1935, 577.

66 'Mr. Baldwin's response', The Times, 23 May 1935, 17. As a general election had not been held since 1931, the meaning of this last remark is unclear, unless it refers to a popular clamour for air defences. It can hardly be considered a reasonable interpretation of the Peace Ballot results.

67 'Nothing short of air parity', Daily Telegraph, 23 May 1935, 14.

68 'R.A.F. (retired)' and Wm. Frith, letters, ibid., 28 May 1935, 16.

${ }^{69}$ Archibald Hurd, letter, The Times, 28 May 1935, 17.

70 'Friends' call to abolish war planes', Daily Herald, 28 May 1935, 6.
} 
Display Committee and the Cambridge Anti-War Council distributed pacifist literature at RAF displays at Hendon, Duxford and Mildenhall. ${ }^{71}$ But among supporters of collective security, the response was not uniform. The Daily Mirror declared that 'the arms race was in full swing', that 'an air war cannot be limited', and that another war would mean the end of Europe. It nonetheless hoped that these 'destructive engines could be turned into a force for the preservation of peace', perhaps a nod in the direction of an international air force. ${ }^{72}$ Heirs of the Radical tradition were surprisingly untroubled by the aerial arms race, but did hold out hope that diplomacy could slow it down. The Economist, for example, found the "“air parity" theory of national defence' unobjectionable, but only so long as diplomatic efforts to lower the level of parity were redoubled. ${ }^{73}$ The Scotsman thought parity essential, if only to provide a stronger bargaining position with Germany. ${ }^{74}$ Oddly, most of these periodicals had supported the air pact in February, but neglected to mention it now. Instead, it was conservative newspapers like the Daily Telegraph and the Observer which invoked the goal of an air Locarno as justification for RAF expansion. ${ }^{75}$ Did the air Locarno provide cover for the abandonment of support for collective security?

The air pact proposal, announced on 3 February 1935, was greeted in the press with a chorus of approval from across the political spectrum. On the left, the Daily Herald declared the Anglo-French proposal 'to be in the fullest accordance with those principles of collective security which are the basis of the League itself'. ${ }^{76}$ On the right, The Times called it 'A constructive agreement' which 'may prove the most valuable contribution to European peace that has been made since Locarno'. ${ }^{77}$ In between, the Daily Telegraph, the Spectator, the Daily Mirror, the New Statesman, and the News Chronicle all supported the air pact to varying degrees. What was the attraction? Simply that, as the Yorkshire Post explained:

No country, however advanced its air armaments, would be likely to launch an opening and sudden air attack on any other if it knew that instantly it would itself be attacked by four Air Forces.

The air pact was ultimately founded on the principle of deterrence, by way of counterbombing. But by bringing Germany within its arrangements, it also attempted to make Germany feel secure against air attack. There was also an important difference from the

${ }^{71}$ E. Vipont Brown and Leah Manning, et al., letters, Manchester Guardian, 26 June 1935, 18; C.B.O. Mohr, letter, New Statesman, 13 July 1935, 58.

72 'What can be done to save Europe?', Daily Mirror, 23 May 1935, 11.

73 'The air debate', Economist, 25 May 1935, 1180.

74 'Herr Hitler's speech', Scotsman, 22 May 1935, 12.

75 'Nothing short of air parity', Daily Telegraph, 23 May 1935, 14; 'Pacts and purity', Observer, 2 June 1935, 16.

76 'Opening the door', Daily Herald, 4 February 1935, 10.

77 'A constructive agreement', The Times, 4 February 1935, 13. 
Locarno pact proper, which had been signed in 1925. Then, Britain (along with Italy) had guaranteed the borders of France, Germany and Belgium against an attack by any one of them. But whereas under the Locarno pact Britain received no promises of aid itself, the air pact was fully reciprocal. So no new commitments were envisaged, and Britain would receive help when it needed it most, when it was in the midst of a knock-out blow from the air. Nor did the air pact compromise efforts to restart the Geneva disarmament talks; in fact it might help, by alleviating Germany's own fear of the bomber. The threat of an arms race and of a knock-out blow would both be lifted. ${ }^{78}$

The only major newspaper to consistently argue against the air Locarno was the Daily Express, a lone sceptic on this issue as with the knock-out blow theory itself.

Beaverbrook's flagship was committed to his vision of 'splendid isolation' and the avoidance of foreign entanglements at all costs. On 4 February its front-page headlines despaired at 'BRITAIN'S STAGGERING PLEDGE: ROYAL AIR FORCE TO BE RUSSHED TO THE CONTINENT AT THE CALL OF OTHER NATIONS'. ${ }^{79}$ It ran a number of leading articles along the same lines. For example, on 9 February it claimed that all the 'Death Pact' would achieve, if signed, would be to force an aggressor Germany to pre-emptively bomb British cities at the same time as it bombed French ones. Since retaliation by the RAF would be automatic in this scenario anyway, Germany would have nothing to lose.$^{80}$ Noting the distrust of the Dominions for anything Locarno, the Express further argued that they might not come to the mother country's aid in the next war. It therefore called on its readers to 'Destroy the air pact. Save the Empire!' and they responded - at least in the paper's letter columns. ${ }^{81} \mathrm{~F}$.W. Brewer of Stevenage congratulated the Express for its 'sensible, courageous and outspoken' condemnation of the air pact, which could only lead to 'the end of Britain as a nation' ${ }^{82}$ For J. Campbell Douglas of West Worthing, the pact was 'a great triumph for French diplomacy' which would inevitably lead to another war and conscription. ${ }^{83}$

The Express claimed that the air pact's early supporters were becoming less sure that it involved no new commitments for Britain. ${ }^{84}$ There was some truth to this, especially on the left. The Mirror noted that whether it was new or not, the air Locarno was a 'dangerous commitment', inviting as it did comparisons with Britain's rush to the defence of Belgium in 1914 and the subsequent 'four and a half years of devastation'. ${ }^{85}$ The Manchester Guardian also now qualified its support, asking how 'automatic' and 'immediate' were defined in the context of the responses demanded by the pact. ${ }^{86}$ The New Statesman had similar concerns, recalling the claims made by Germany of French

\footnotetext{
78 'Britain and France take action', Yorkshire Post, 4 February 1935, 8.

79 'Britain's staggering pledge', Daily Express, 4 February 1935, 1.

80 'Marching to war', ibid., 9 February 1935, 10.

81 'Covenant with death', ibid., 5 February 1935, 10.

${ }^{82}$ F.W. Brewer, letter, ibid., 8 February 1935, 10.

${ }^{83}$ J. Campbell Douglas, letter, ibid., 6 February 1935, 10.

84 'A loaded pistol', ibid.

85 'What if the new pact is confirmed?', Daily Mirror, 5 February 1935, 11.

86 'Some questions', Manchester Guardian, 6 February 1935, 8.
} 
violation of its airspace in August 1914, which suggested the difficulty of verifying who was to blame for an attack by air. It thought that the best that could be said for the AngloFrench proposal was that it might ultimately lead to a pan-European air force. ${ }^{87}$ But the air pact soon became an accepted part of Europe's diplomatic language, with discussions on its prospects held in Paris, Rome, Berlin and Brussels as in London. The Conservative Yorkshire Post dismissed opposition to an air Locarno as 'the expected clamour of a few wholly unpractical "isolationists", but this was not true. ${ }^{88}$ Much of the criticism in the letters columns in fact came from supporters of collective security, who feared that an air pact would undermine the League of Nations. For example, one woman wrote to the Scotsman from Edinburgh asking why Britain should trust the other Locarno powers to come to its aid, when the Covenant of the League already required all members to give assistance to any country under attack $?^{89}$ Others, like Maxwell Garnett, the general secretary of the LNU, did see some value in an air Locarno, hoping that it could lead to a disarmament agreement, enabling air parity with Germany to be reached at a lower level than would otherwise be the case. ${ }^{90}$ But even support for the air pact was rarely couched in terms other than its value for collective security, and by the right more than the left.

'Air panic' is a phrase occasionally used by historians to describe the events of late 1934 and early $1935 .^{91}$ That a panic or scare had taken place was also claimed at the time, particularly after the May 1935 RAF expansion - the third such in less than a year, none of which were announced as part of the annual Air Estimates, as was usual. The Aeroplane even entitled its (by no means unfavourable) leading article on the affair 'Reflections on the air panic'. ${ }^{92}$ Comparisons with earlier panics about the defence of Britain were drawn: for the Marxist Tom Wintringham, writing shortly afterwards, the obvious parallel was the 1909 dreadnought panic:

The decision to make these preparations for war from the air in the near future was 'put over' by a press campaign almost on a level with the campaigns of the war period, and certainly stronger than the agitation for more battleships ('We want eight and we won't wait') that helped the Liberal Government of 1906-14 to get ready for the crushing of Britain's commercial rival, the German Empire. ${ }^{93}$

\footnotetext{
87 'The air pact', New Statesman, 23 February 1935, 236-7.

88 “"A basis for negotiations", Yorkshire Post, 5 February 1935, 10.

${ }^{89}$ Dorothy Williams, letter, Scotsman, 6 February 1935, 13.

${ }^{90}$ Maxwell Garnett, letter, Manchester Guardian, 5 February 1935, 20.

${ }^{91}$ E.g., Bialer, Shadow of the Bomber, 68; Martin Gilbert, Winston Churchill: The Wilderness Years (London 1981), 114. It has also been applied to other episodes in the early twentieth century: see Alfred Gollin, The Impact of Air Power on the British People and their Government, 1909-14 (Stanford 1989), chapter 11; Holman, op. cit., 220-98.

92 'Reflections on the air panic', Aeroplane, 29 May 1935, 613-4.

${ }^{93}$ T.H. Wintringham, The Coming World War (London 1935), 111-2.
} 
Groves, whose book Behind the Smoke Screen had been published in January 1934, was held responsible for the panic by some writers. ${ }^{94}$ While this classic work on the knockout blow was widely read and quoted - J.L. Garvin in the Observer called it 'not merely a book but an event' - the press and the government had by far the greater share of blame for creating a sense of crisis. ${ }^{95}$ When the chiefs of staff expressed doubts about the feasibility of an air pact, MacDonald retorted that they 'had not appreciated sufficiently the political aspect of the proposal'. Later, Scheme C was allowed to go forward even though it necessitated the 'immediate placing of production orders, before prototypes have been tested, for certain types of aircraft', a risky proposition indeed. ${ }^{96}$ Such actions do indicate excessive alarm within the government at the aerial danger. But it was the press which interpreted the new arms race to the public, and which had most agency in choosing how to respond. If anyone panicked, it was Fleet Street, and especially the right-wing side of it. But to what purpose?

It was a longstanding Radical criticism that press panics about defence favoured the right, who were traditionally associated with support for military spending. Indeed, the first three decades of the twentieth century seemed to confirm this pattern, with particularly intense press alarms over supposed naval or aerial weakness taking place in 1909, 1913 and 1922, fanned by Conservative-leaning newspapers. ${ }^{97}$ Taken together with spy scares, invasion scares and red scares, the right did indeed seem particularly prone to panic. $^{98}$ Such defence panics served to rally public support for increased armaments, though governments were not always swayed, as was the case in 1913. The situation in 1935 was somewhat different, because of the pacifist mood of the public. Indeed, by April both Beaverbrook and Rothermere thought that 'too much insistence upon the imminence of war and the need for defence is harming the papers'. ${ }^{99}$ The problem was not that rousing

${ }^{94}$ E.g., H. Rowan-Robinson, Security? A Study of our Military Position (London 1935), 66.

95 J.L. Garvin, 'Air and life', Observer, 28 January 1934, 14.

${ }^{96}$ CP 43 (35), 25 February 1935, CAB 24/253; CP 106 (35), 20 May 1935, CAB 24/255.

${ }^{97}$ The classic Radical statement of the charges against Conservative scaremongering is Richard Cobden, The Three Panics: An Historical Episode (London n.d. [1862]). On the previous naval and air panics, see A.J.A. Morris, The Scaremongers: The Advocacy of War and Rearmament, 1896-1914 (London 1984), 164-84; Gollin, op. cit.; Powers, op. cit. Left-wing defence panics did occasionally occur, as with the deep shelter campaign of the late 1930s and early 1940s: Noreen Branson, History of the Communist Party of Great Britain 1927-1941 (London 1985), 183-7; Mackay, op. cit., 33-5.

${ }^{98}$ Morris, op. cit.; Boghardt, Spies of the Kaiser: German Covert Operations in Great Britain During the First World War Era (Basingstoke and New York 2004); Anne Perkins, A Very British Strike: 3 May-12 May 1926 (London 2007).

${ }^{99}$ Collin Brooks diary, 3 April 1935, Crowson, op. cit., 95. This is a contrast to the Edwardian period, when Rothermere's brother Northcliffe found scaremongering a reliable way of increasing circulation, as in 1906 when William le Queux's The Invasion of 1910 was serialised in the Daily Mail. I.F. Clarke, Voices Prophesying War: Future Wars 1763-3749 (Oxford and New York 1992), 122-4. 
the people to their aerial danger was terribly difficult, but that they now had a different response in mind, as the Peace Ballot showed: collective security.

The key to the evolution of the press debate, and perhaps of public opinion itself, was therefore not rearmament or air parity themselves, to which attitudes had long since hardened. Rather, it was the surprising Anglo-French suggestion, in February 1935, of an air pact between the Locarno powers. The importance of the air pact has been obscured by its non-existence: after 1936, it dropped off both the international and the domestic agenda, apart from occasional bouts of wishful thinking. It plays little part in the narrative of appeasement and rearmament which structures our understanding of the $1930 \mathrm{~s} .{ }^{100}$ But for a time, it promised to go far towards removing Britain's air danger. It soon came to mean different things to left and right, however.

Northcliffe's Daily Mail suggested that the Conservatives, divided over India and disarmament, could use the air Locarno proposal to reunite. ${ }^{101}$ That the announcement was made on the same weekend as the disastrous Wavertree by-election result, which Churchill's son Randolph caused by running as an independent conservative, may have reinforced this impression. But there was little sign of this. Churchill himself was lukewarm on the prospect of an air pact, and his so-called air defence campaign was only just beginning. The air pact idea was more useful in enabling the move from prodisarmament to pro-rearmament positions by a number of newspapers, such as The Times and the Scotsman. It was malleable enough to be used in support of parity, disarmament or collective security itself, and in the shorter term plausibly provided Britain with insurance against a German air attack. In deterrence terms, it would have greatly increased the effective size of the air force defending Britain at no additional financial cost. It also left the door open for future rearmament measures, if the German air force continued to expand. The risk was in its provisions for automatic, instantaneous response to an attempted knock-out blow: these could drag Britain into a war without regard to the issues at stake, whether of principle or (more importantly) self-interest. In the age of the knock-out blow, however, speed was everything, and these risks seemed to the government to be worth taking. The support the air pact received in the press would have suggested to Baldwin that the way was open for public opinion to shift towards more wholehearted support for rearmament in defence of collective security, as he was later to campaign for in the 1935 general election. But in attempting to legitimise German rearmament and alleviate its security concerns, the air pact also represented the first act of appeasement.

By contrast, the left-wing and Liberal press - and many of its readers - soured on the air pact, after strong initial enthusiasm. The reason for this was the one offered by the right in support: the need to support collective security. It was precisely the same flexibility of the air pact with regards to parity that allowed the right to accept it which damned it in

${ }^{100}$ The air pact is not mentioned, for example, in the relevant volume of Churchill's official biography: Martin Gilbert, Winston S. Churchill (London 1976), volume 5, nor is it mentioned in Winston S. Churchill, The Gathering Storm (London 1948).

101 'Get together', Daily Mail, 9 February 1935, 10. 
the eyes of the left, for which collective security did not mean the bombing of civilians. This chance to grasp the need for rearmament was lost, and so the left in general, and Labour in particular, remained caught between the idealism of moral force and the pragmatism of physical force, to borrow the terms of an earlier age. It was not to fully resolve this dilemma about how best to oppose fascism until the Spanish Civil War, or even after Munich, ensuring that Britain was not fully united on its path towards war until it was almost upon it. 